\title{
Judging without Impunity: On the Criminal Responsibility of Authoritarian Judges
}

\author{
HANS PETTER GRAVER
}

\section{Immunity, Accountability and Judicial Independence}

When a regime commits itself to the oppression of its people, by persecuting minorities or political opponents, depriving people of their personal liberty and even outright killings, we do not hesitate to hold those responsible accountable. We blame the politicians and leaders who make the decisions, and also those who implement the evil measures.

In some cases, leaders employ the service of the courts in order to obtain their aims of oppression. Repression may take place both outside of and inside of the law. Once it is judges who order and enforce the oppressive measures are ordered and enforced by judges, they are often perceived differently from when they are taken outside of the scope of the judiciary. Judges in fact have a high degree of protection from responsibility for their judicial actions. Historical examples show that it is very difficult to make judges accountable for their conduct on the bench.

Take the example of the 'euthanasia' programme of Nazi Germany that killed more than seventy thousand people. Most would not hesitate in characterising this as a programme of extermination, and call for the punishment of those taking part in it. ${ }^{1}$ The same characteristic is not often used to describe the institution of special and military courts that killed more than thirty-five thousand people, many of them between 1941 and 1945. Reportedly, only one German judge was convicted for this in The Federal Republic of Germany. German courts after the war decided that both doctors and judges

* $\quad$ Professor, Faculty of Law, University of Oslo.

1 See Freudiger, Die juristische Aufarbeitung von NS-Verbrechen (Mohr Siebeck 2002) pp. 108-119.

This is an Open-access article distributed under the terms of the Creative Commons Attribution 3.0 Unported License (http://creativecommons.org/licenses/ by/3.0/, permitting all use, distribution, and reproduction in any medium, provided the original work is properly cited. 
were acting illegally. However, whereas doctors were punished, judges could only be punished if they had acted out of malicious motives. In no case did the courts after the war find proof of this.

The question addressed in this paper is if, and how far, it is possible to reconcile to hold judges accountable under criminal law for participation in the oppression by an authoritarian regime, with the principle of judicial independence. On the one hand, judicial independence protects the judges against liability for acts performed in the exercise of their function. On the other hand, justice demands that those responsible for the wrongdoings of an evil regime should be held accountable, even under conditions where the wrongdoings were sanctioned by the law of the regime. There is a vast and growing amount of literature on judicial independence. ${ }^{2}$ However, surprisingly little of this deal with the issue of criminal liability of judges and most seems to take for granted that a judge must have immunity against criminal sanctions. I will challenge this idea in the following.

There are other ways of sanctioning judicial wrongdoing than by criminal law, notably through disciplinary measures and the removal of judges. In particular, codes of judicial conduct and mechanisms for enforcing judicial discipline seem to be on the rise and playing an increasingly important role for the legitimacy of the judicial function. ${ }^{3}$ There are connections and relations between the different sanctions, which all raise issues of judicial independence. In some jurisdictions, such as the US and Germany, the removal of a judge requires proof of criminal conduct or a serious abuse of office. ${ }^{4}$ The same conditions for removal are consistently prescribed by the Venice Commission. In other jurisdictions, the inability of a judge to function in a normal way in a collegial work-environment may be grounds for dismissal. A Norwegian judge was recently dismissed on this ground after a legal procedure in the normal courts. ${ }^{5}$

I will, however, not elaborate on the use of other sanctions than criminal liability. I am also not primarily concerned with the sanctioning of aberrant judges operating in a society where the rule of law is respected as a general rule. My focus will primarily be on judges who have collaborated with regimes that negate or undermine the rule of law in a more systematic way. Yet, since the liability of judges, and the other side of the coin, ju-

2 See for example Salas and Épineuse (eds.) L' étique de juge: une approche européenne et internationale (Dalloz 2003), Judicial Independence in Transition, ed. Siebert-Fohr (Springer 2012) and The Independence of Judges, eds. Engstad, Frøseth and Tønder (eleven international publishing 2014).

3 See Di Federico, Judicial Accountability and Conduct: An Overview in Judicial Independence in Transition, ed. Siebert-Fohr (Springer 2012) p. 89.

4 See Jackson, Judicial Independence: Structure, Context, Attitude, in Judicial Independence in Transition, ed. Siebert-Fohr (Springer 2012) p. 51.

$5 \quad$ See case no LB-2013-171610-2 by Borgarting lagmannsrett (Court of Appeals) 1 July 2014. 
dicial immunity, are inextricably linked with the status of the judge, my conclusions will inevitably be of general relevance.

The question of holding judges responsible for upholding oppressive laws has direct relevance beyond the case of the Nazi judges. Not all judicial oppression has the extreme character of Nazism - in some situations involvement of the courts is necessary to dispose of political enemies by death or imprisonment. In other cases, the use of the courts may only be a matter of choice or of convenience. ${ }^{6}$ In the legalistic culture of $21^{\text {st }}$ century Europe, authoritarian rulers often see the need to involve the courts in their desire to hold onto power. For example under the so-called Revolution of Dignity in Kiev, Ukraine, November 2013 to February 2014, the courts participated in the endeavours of the state to quash the protests. According to a study of approximately 500 cases from first instance and appeal courts, from 21 December 2013 to 22 February 2014, this was done largely under disregard of procedural rules and safeguards of the Ukrainian constitution and law of criminal procedure. ${ }^{7}$

The public opinion after the fall of Yanukovych was outraged, and demanded that the judges should be held responsible for their participation in the suppression of the protesters against the regime. Laws were enacted by the parliament to this end, and institutions to investigate were established, but up to now only a few judges have been held accountable.

The experiences from these two very different historical events are typical when it comes to the dealing with judges in authoritarian settings - justice demands to hold also judges accountable. Nevertheless, like their colleagues in societies that uphold and respect the rule of law, such judges are in practice awarded immunity for their judicial actions, an immunity that is even to a point demanded by the rule of law itself. Judges in authoritarian - and Rule - of - Law societies alike are protected by an appeal to the important principle of judicial independence, which protects against personal liability for judicial decisions. The immunity of judges should not be without limits, however, and should not go further than what the rule of law requires. Judges should not only be independent, they should also be accountable.

The purpose of this article is to examine how far, with due respect for the rule of law, criminal sanctions could be applied to judges for the exercise of their judicial functions. My main focus will be on situations where judges are employed by the holders of power in the realisation of political oppression. In order to address this question it is necessary to look into the criminal responsibility of judges more generally. Applying criminal sanc-

6 See Kirchheimer, Political Justice The Use of Legal Procedure for Political Ends (Princeton University Press 1961) pp. 95-96 and 419 ff.

7 Navrotskyi, Fair, Independent and Accountable Judiciary in Ukraine Analysis of the Practice of Custodial Measures Enforcement During the «Revolution of Dignity» Events, unpublished paper produced for USAID 15.10.2015. 
tions to a judge for his or her judicial action may challenge the principle of judicial independence. Still, should this principle award judges with a greater immunity from punishment than other servants of an oppressive state? My focus will mainly be on instances of transition, from an authoritarian setting to the rule of law. In such instances, standards change. What was perceived as necessary and defensible under certain conditions may be perceived as illegitimate under the new conditions.

The question of judicial liability can also arise when conditions are stable. Even within a well-functioning judiciary that operates in accordance with the rule of law, one can sometimes come across instances where a judge deviates from the norm. He may for instance accept bribes or hand down decisions that depart from what anyone will recognise as a reasonable judgement of the facts or application of the law. The need to punish such offences must be balanced against the principle of judicial immunity. Under the condition of well-functioning courts, this balance is achieved by the fact that the aberrant judge is tried by his peers. This ensures that the effect on the judicial role is taken into account, and that it is not undermined by penalizing a judge. ${ }^{8}$

In transitional settings, the same principle applies. However, the justification of punishment under normal circumstances cannot be applied so easily to situations where wrongdoings are common and sanctioned by the state. ${ }^{9}$ In addition, in many cases of transition, the role of the judiciary is precarious, and the rule of law often not yet properly entrenched. This increases the risk that sanctioning judges undermine judicial independence and thus pave the way for the rule of law more difficult. On the other hand, it may be argued that holding judges accountable for their participation in the misdeeds of an oppressive regime is important to strengthen the role of the judiciary in a post-authoritarian society. ${ }^{10}$

After some introductory remarks on transitional justice, I will present the international standard of judicial immunity and the reasons behind it (2). Then I will present the normative basis for holding judges accountable by referring to some different examples

8 Standards change also in societies with institutions continuously based on democracy and rule of law. In many of the Western democracies, values and perceptions have changed, in particular regarding the treatment and rights of minorities such as indigenous peoples and travelling people. Some decades ago, many countries practiced hard policies of assimilation that entailed prohibition of minority languages and even measures of sterilisation of women and removal of children into the custody of public bodies. Judged by today's standards such measures are immoral and illegal. I will not address the difficult issue of whether and how to deal with officials or judges responsible for implementing such policies under current standards. For a more general treatment of how societies are trying to right the wrongs of the past see Historical Justice in International Perspective How Societies Are Trying to Right the Wrongs of the Past, eds. Berg and Schaefer (Cambridge University Press 2008).

9 Murphy, Transitional Justice, Retributive Justice and Accountability for Wrongdoing in Theorizing Transitional Justice, eds. Corradetti, Eisikovis and Rotondi (Ashgate 2015) pp. 63-66. 
of national laws (3). Rules are one thing, practices another. The next section looks into the few historical examples of judges that have been held accountable under criminal law (4). Finally, I will make the case for an increased liability for judges under certain circumstances, and the conditions that must be fulfilled (5).

\section{Challenges of Transitional Justice and Judicial Immunity}

Transitional justice, in the form of criminal sanctions against members of a past oppressive regime, has its dilemmas and legal challenges. ${ }^{11}$ For this purpose, many countries for good reasons opt for more conciliatory approaches. ${ }^{12}$ Having overcome the authoritarian stage, the country often needs to look forward to establish robust and just institutions. In order to achieve this, many societies have decided not to dwell on injustices of the past. Such considerations also enter the picture when one is considering the responsibility of judges for the wrongdoings of the previous regime. Nevertheless, holding judges accountable raises difficult questions, in addition to all the general questions of transitional justice. It is widely held that the independence of the judiciary rules out any liability for judges based on their interpretation and application of the law, and that this also applies to transitionary situations.

Judges hold a special position when it comes to being held accountable for oppressive measures enacted by those in power of the legislator or the executive. Judges should not have to deliberate and take into account what consequences a ruling might have for them personally. ${ }^{13}$ Lack of immunity might also leave the path open for applying pressure on judges to decide in accordance with the wishes of those in power. According to widely held views, judges should not be held accountable for their actions in this role by other means than an obligation to give reasons, and being subject to review through a system of appeal. The Committee of Ministers of the Council of Europe states in its recommendation on judges that:

the interpretation of the law, assessment of facts or weighing of evidence carried out by judges to determine cases should not give rise to civil or disciplinary liability, except in cases of malice and gross negligence. ${ }^{14}$

11 See Teitel, Transitional Justice (Oxford University Press 2000) chapter two.

12 See Rotondi and Eisikovits, Forgetting after War: A Qualified Defense, in Theorizing Transitional Justice, eds. Corradetti, Eisikovis and Rotondi (Ashgate 2015).

13 See Helmke, Courts under Constraints Judges, Generals, and Presidents in Argentina, (Cambridge University Press 2005) for a theoretical and empirical account of how fear of sanction may influence judicial decision-making. Under given conditions, any judge may opt to act strategically, see Helmke p. 34.

14 Recommendation CM/Rec (2010)12 of the Committee of Ministers to member states on judges: independence, efficiency and responsibilities paragraph 66 . 
Criminal sanctions should only be applied 'in cases of malice. ${ }^{15}$ According to this recommendation, a judge should only be held accountable if he acted with the intent to misapply the law for extraneous reasons. One could say that such a judge is not acting as a judge, but is pursuing illegitimate aims under the cover of law.

This statement underscores the immunity of judges, but also the limits of such immunity. Judges are generally not protected from sanctions against misconduct and gross misbehaviour, such as corruption or misuse of power. As stated by the Consultative Council of European Judges, 'the corollary of the powers and the trust conferred by society upon judges is that there should be some means of holding judges responsible, and even removing them from office, in cases of misbehaviour so gross as to justify such a course. ${ }^{16}$ Such standards mostly refer to the extra-judicial activities of judges, or to their use of their power to follow extraneous goals. When it comes to their well-intended judicial acts, things are different. According to this, judges are, after all, only applying the laws that they themselves are not responsible for. Consequently, they must be given wide margins for mistakes and oversights, even if this amounts to clear misapplication of the law.

In many countries, a judge has immunity without the distinction between official and unofficial actions. The Polish Constitutional Court states the purpose behind such immunity in a ruling on an amendment of the Polish act:
International regulations emphasise that not only the actual, but also the apparent dependence of courts (judges) in their jurisprudential practice on factors other than the requirements of the law may constitute an infringement of the standards of the inde- pendence of courts and judges. It stems from the jurisprudence of the European Court of Human Rights that immunity protects guardians of the administration of justice against the influence from political groups, provocation, retaliation or external pressure. In fact, immunity serves to ensure the stabilisation of adjudication by way of limiting the possibility of the exertion of influence on the content thereof by factors from outside the administration of justice. The mechanism constitutes a guarantee of the separate- ness of the judiciary from other powers. Furthermore, its goal is to protect the integrity of judges exposed to a revenge on the part of persons who had been judged contrary to their expectations. ${ }^{17}$

The court here expressed what could be seen as the more general rationale behind judicial immunity, which is accepted in most countries. Similarly, the European Commission for Democracy through Law (Venice Commission) sees the issue of criminal and

$15 \quad$ See paragraph 68.

16 Opinion no 3 of the Consultative Council of European Judges (CCJE) on the principles and rules governing judges' professional conduct, in particular ethics, incompatible behaviour and impartiality paragraph 51 .

17 Judgement of 28th November 2007, K 39/07 PROCEDURE FOR DEROGATION OF JUDICIAL IMMUNITY (OTK ZU 2007, No. 10A, item 129 ) paragraph 14 (accessed 20.05.2016 at http:// trybunal.gov.pl/fileadmin/content/omowienia/K_39_07_GB.pdf) 
civil liability and immunity of judges in the light of the importance to safeguard judicial freedom from undue external influence. In the view of the Commission, however, this does not reach further than to protect judges against liability for acts performed in the exercise of their function. Outside of his or her judicial function, there is not the same basis for giving judges a privileged position against criminal investigation and charges. The Venice Commission therefore consistently opposes legislation on immunity that extends beyond functional immunity. ${ }^{18}$ However, judges should enjoy functional immunity, according to the commission, with the exception of intentional crimes, e.g. taking bribes. ${ }^{19}$

The reasons to give judges immunity are general in their application, and are held to be relevant in cases against judges of former oppressive regimes. Offensive as their rulings might be, judges are often neither making the law, nor breaking it. Their role is to apply the law, and to disregard their own personal moral or political assessments of the appropriateness of the law that they are applying. In relation to Ukrainian reactions against judges who enforced measures against people taking part in protests on the winter of 2013-2014, the Venice Commission has stated that it is 'essential not to blame judges for' rulings in 'cases which at the time when the judge took the decision did represent criminal offences'. ${ }^{20}$

This approach is based on a view of the judge, which is not wholly satisfactory. Examples, particularly from the experience of post-communist states, show that judicial immunity is often misconstrued to cover up judicial shortcomings. ${ }^{21}$ There is often a scope for judicial discretion in the evaluation of the evidence and in the interpretation and application of the law. If a judge systematically employs this discretion in support of an authoritarian regime, is not the judge equally to blame as the person who enacts the oppressive rules? Judicial immunity is not an end in itself. ${ }^{22}$ On the other hand, judges should not be inhibited in their exercise of judicial discretion by the fear of someone disagreeing with the choices they make. This is particularly significant in the light of an

18 See European Commission for Democracy through Law (Venice Commission) Report on the Independence of the Judicial System Part 1: The Independence of Judges, adopted by the Venice Commission at its 82 ${ }^{\text {nd }}$ Plenary Session, Venice, 12-13 March 2010 CDL-AD(2010)004 paragraph 60-61.

19 European Commission for Democracy through Law (Venice Commission) Report on the Independence of the Judicial System Part I: The Independence of Judges, Adopted by the Venice Commission at its 82 ${ }^{\text {nd }}$ Plenary session, Venice, 12-13 March 2010 CDL-AD(2010)004.

20 European Commission for Democracy through Law (Venice Commission) Interim Opinion On the Law on Government Cleansing (Lustration Law) of Ukraine, Adopted by the Venice Commission at its $101^{\text {st }}$ Plenary Session (Venice, 12-13 December 2014) CDL-AD(2014)044 paragraph 77.

21 Bobek, The Fortress of Judicial Independence and the Mental Transitions of the Central European Judiciaries, 14 European Public Law (2008) pp. 99-123 p. 100.

22 See further Yusuf 2010 pp. 18-20 
observed general tendency among Europe's political classes to subject judges to control. ${ }^{23}$ This calls for a careful balancing of the different considerations when deciding on judicial liability.

\section{The Normative Basis for Liability}

Different national laws on the criminal responsibility of judges reflect general views of restraint in criminalizing judicial acts. A survey performed by the Consultative Council of European Judges shows that some countries award the judiciary complete immunity from prosecution. ${ }^{24}$ In other countries, specific acts of misconduct can give rise to criminal investigations. Typical examples are corruption, misuse of power and misconduct such as breach of rules of professional secrecy and abusive or discriminatory behaviour from the bench. The survey is based on the legislation of the responding countries, and gives no information about to what extent and how the legislation is actually enforced.

In England and Wales, judges are immune where they act in the bona fide exercise of their office, in the belief that they have jurisdiction. ${ }^{25}$ In some jurisdictions, the legislation goes further in specifying certain judicial acts that can be sanctioned as illegal. Under some laws, judges can be brought to account for deliberate delivery of illegal decisions or conscious conviction of innocent persons.

Other countries have laws that criminalise collusion with the police and security forces in the use of illegal procedures in order to obtain admissions from a defendant. Such judicial acts may be the ordering of illegal arrests or investigations. An example of this is found in Icelandic law. The law specifies the active use of illegal procedures and ordering of illegal arrests or investigations. One of the most common forms of judicial support to authoritarian measures, however, is a judicial policy of non-interference, allowing the regime to pursue an illegal oppression of opposition, concentrating on the substance if and when cases are brought to court. ${ }^{26}$ When this is regular practice, police and prose-

23 Laffranque, Judicial Independence in Europe: Principles and Reality in The Independence of Judges, eds. Engstad, Frøseth and Tønder (eleven international publishing 2014) p. 139.

24 See Opinion no 3 of the Consultative Council of European Judges (CCJE) on the principles and rules governing judges' professional conduct, in particular ethics, incompatible behaviour and impartiality.

25 Turenne, Judicial Independence in England and Wales, in Judicial Independence in Transition, ed. Siebert-Fohr, (Springer 2012) p. 172.

26 See for details Graver, Judges Against Justice On Judges When the Rule of Law is Under Attack, (Springer 2015) chapter 4 and for a practical example from the judicial system of Ukraine ECtHR Case Kaverzin v. Ukraine, (Application no. 23893/03) Judgement 15 May 2012 paragraph 178. According to the Court, a failure by the national courts to investigate into allegations of torture of persons held in police custody was a systemic failure of the Ukrainian court system, perpetuating ' $a$ climate of virtually total impunity for such acts', and constituted a violation of Article 46 of the ECHR. 
cutors can transgress the rights of the arrestees and defendants with impunity. When the law requires, as in Icelandic law, that illegal measures must be ordered or permitted by a judge, the judge can only be held responsible when it is the judge who orders or applies the illegal measures of investigation. One might argue that the misdeed of the judge is comparable to when the judge disregards a number of gross violations of the procedure by the police or the prosecutors, and blindly approves the arrest of a defendant or imposes a fine.

The problem with all laws criminalising illegal acts by judges is that the legality of an act often follows from the fact that it is a judicial act. In order for it to be illegal, and not merely wrong from a legal point of view, the judge must exceed the scope of discretion and interpretation that the law awards the judge. This raises no problems if the judge is motivated by extra-legal factors, such as revenge, the fulfilment of a promise, or obedience to an order or a threat given by an outsider, such as a superior judge or a member of the administration or the ruling party. This is equally evident if the judge, in conscious violation of the law, takes into account what he or she perceives are in the interests of society or any party related or unrelated to the case at hand. Likewise, an act cannot be legal as a judicial act if it results from proceedings without any resemblance to the notion of a fair and impartial trial. Consequently, if illegality is a condition for holding a judge accountable, accountability in practice will only come to bear on judges with malicious or extra-legal motives for their acts. If one wants to extend the possibility to punish onto intended judicial failings, the law must also criminalise certain legal judicial acts or at least acts that are perceived as legal at the time they are performed.

Yet, on what basis can one hold a judge responsible for breaking a law if he is applying the positive law correctly? Gustav Radbruch grappled with this question after the fall of the Nazi regime. His conclusion was that laws which were in flagrant contradiction with any conception of justice, had to be regarded as 'unlaw'. As a result obedience to them had to be regarded as unlawful if the consequence were to be the deprivation of someones life or personal freedom. ${ }^{27}$ Radbruch's answer was in other words to disregard the laws empowering the judge to give rulings. Thereby his acts would be illegal if they infringed on other valid legal rules, such as the prohibition to take the life of another human being - which was illegal also under the law of Nazi Germany. Murder is and was a criminal offence. The laws of Nazi Germany criminalising acts against the state were the grounds a judge could use to justify the ordering of an execution. But since these laws were in flagrant contradiction with the laws of any civilized nation, they had to be regarded as

27 Radbruch, Gesetzliches Unrecht und übergesetzliches Recht, Süddeutsche Juristen-Zeitung (1946) 105-108 [English translation Statutory Lawlessness and Supra-Statutory Law, Translated by Bonnie Litschewski Paulson and Stanley L. Paulson, 26 Oxford Journal of Legal Studies (2006), pp. 1-11]. 
'unlaw' in Radbruch's conception. Thus, the judge's contribution to the killing was no longer justified, and thus illegal. ${ }^{28}$

A different approach follows from the observation that an action can be governed by different sets of rules, so that it is legal under one set, but illegal under another. After the war, members of the German judiciary were convicted by the US military tribunal. This was based on the fact that certain acts were considered crimes under international law, and their legality under national German law was not counted as a valid defence. The different rule-sets might also be different sets of national rules, so that an action performed under a certain regime can be illegal under the rules in force prior to or after the regime, when the contested rulings are made. To hold a person accountable under previous or succeeding legal rules means that one has to apply these rules anachronistically, for example retroactively. This entails departing from an important part of the rule of law. This should, however, not be ruled out if it is necessary to fulfil other important demands of the rule of law. It follows, for example, from Article 7 (2) of the ECHR that the prohibition against punishment without law does 'not prejudice the trial and punishment of any person for any act or omission which, at the time when it was committed, was criminal according to the general principles of law recognised by civilised nations'. In its judgement on the responsibilities of the leaders of the GDR for the killing of persons trying to cross the border into West-Germany, the ECtHR stated that 'the courts of such a State [a state governed by the rule of law] having taken the place of those which existed previously, cannot be criticised for applying and interpreting the legal provisions in force at the material time in the light of the principles governing a State subject to the rule of law. ${ }^{29}$ The aim of the prohibition against retroactive law as a basis for punishment is to prevent anyone from being subjected to arbitrary prosecution, conviction or punishment. However, to sanction flagrant departures from the rule of law and serious infringements of basic human rights is not arbitrary from the point of view of the rule of law.

28 Following the debate between Lon Fuller and H.L.A. Hart in 1957 there has been a large number of contributions to the discussion of whether the concept of law must include or exclude unjust laws. This theoretical question is not my focus here. I am merely looking for different ways to argue for holding judges accountable for misdeeds that are regarded as legal at the time they are committed.

29 ECtHR case of Streletz, Kessler and Krenz v. Germany (Applications nos. 34044/96, 35532/97 and 44801/98) judgement 22 March 2001 paragraph 81. 


\section{Judicial Liability in Practice}

\subsection{Introduction}

Experience shows that judges are rarely brought to answer for their oppressive deeds from the bench. ${ }^{30}$ Successor regimes in general seem to be more concerned with reconciliation and bridging social clefts than about retribution and criminal sanctions. Even in cases where perpetrators of the oppression are brought to account, the judges are treated more leniently than others are.

There are, in fact, only two instances in recent history where the responsibility of judges has been the serious concern of criminal law, both in settings of transitional justice; after the breakdown of the Nazi regime, and after the reunification of the two German states in the 1990s. The judiciary was a topic for the Truth and Reconciliation committees of South Africa and Chile. It was subject to criticism, but no sanctions were applied.

In Ukraine, there has been discussions about holding judges accountable, both for their role in the suppression of political opposition during the 2013-2014 protests, and for their protection of officials involved in serious crimes against protesters. A judge, who released a commanding officer under suspicion of commanding a unit which shot dead 49 protesters on 20 February 2014, was later made the subject of criminal proceedings under the suspicion of making a deliberate unjust ruling. ${ }^{31}$ Disciplinary measures have also been taken against a handful of other judges involved.

\subsection{The post-Nazi Cases}

The main body of case law on criminal responsibility of judges in oppressive regimes thus stems from the few international and national cases after World War II and from German cases after the reunification. ${ }^{32}$ The main international case is the US Military Tribunal

30 See Graver 2015, Dommernes krig (Pax 2015) where I give a more detailed references and an account of judicial complicity in several authoritarian regimes in Western countries in the late twentieth century.

31 See Report of the Council of Europe Advisory Panel on its review of the Maidan Investigations, 31 March 2015 pp. 80-82.

32 The trails conducted in countries under Soviet influence after World War II, such as the Waldheimer trials in the GDR in the beginning of the 1950ies were mere show trials directed by the Central Committee of the Communist Party, see Falco Wertkentin, Strafustiz im politischen System der DDR: Fundstücke zur Steuerungs- und Eingriffspraxis des zentralen Parteiapparates der SED in Steuerung der Justiz in der DDR Einflussnah, ed. Rottleuthner. Such trials can therefore not be counted as examples of defendants being held accountable under criminal law, but must rather be seen as administrative acts in disguise, see Kirchheimer 1961 p. 426. 
'Justice Case' against leading officials of the Nazi legal system. ${ }^{33}$ The accused were tried under international law and convicted for war crimes and crimes against humanity. ${ }^{34}$ Most of the accused had held office in the Ministry of Justice, and were convicted for their role in developing and implementing rules based on the policies of the Nazi regime. These convictions do not raise the issue of holding judges accountable in their capacity as judges.

Those convicted in a judicial capacity were found guilty of discriminatory persecution and application of oppressive laws against Jews and Poles, as well as of applying and enforcing the Nacht und Nebel legislation against nationals from occupied countries. This programme was a scheme where persons accused of resistance were brought to Germany and convicted in secrecy. They had no opportunity to defend themselves and were subsequently brought to disappear in the 'night and fog' of the concentration camps. The tribunal did not regard as crimes judicial acts that did not involve application of schemes deemed as war crimes, or that were not discriminatory in a way to constitute crimes against humanity. Four out of the six accused, who had only acted in their judicial capacity during the Nazi regime, were acquitted by the tribunal.

Several judges were accused in West-German courts, but were acquitted for the lack of malicious intent. The first case where the Supreme Court of the German Federal Republic was asked to rule directly on the criminal liability of a judge was a case in 1952 against judges of a military tribunal. The judges had after the capitulation of the German forces in May 1945 convicted three sailors to death for desertion. ${ }^{35}$ The Supreme Court stated that disproportional punishments were against an 'unwritten basic assumption of German criminal law'. The position would entail that judges who had applied death sentence to persons accused of relatively insignificant offences would be liable to punishment. This caused former judges to mobilise. ${ }^{36}$ In later cases, the courts departed from this line of reasoning. The position was reversed in a ruling from 1956 against Dr. Otto Thorbeck and Walter Huppenkothen. ${ }^{37}$

Thorbeck and Huppenkothen were charged as judge and prosecutor of an SS Tribunal. The tribunal tried admiral Canaris and several of his associates in the concentration camps of Sachsenhausen and Flossenbürg on April 6 and 81945 for participation in

33 Trials of War Criminals before the Nuremberg Military Tribunals, vol. III, the Justice Case, Washington 1951. For a presentation and discussion of the case see Fraser 2012.

$34 \quad$ See further Graver 2015 chapter 7.

35 BGH, Urteil vom 29. 5. 1952 - 2 StR 45/50.

36 See Garbe, Im Namen des Volkes?! Die Rechtlichen Grundlagen der Militärjustiz im NS-Staat und ihre "Bewältigung" nach 1945 in Erinnerungsarbeit Grundlage einer Kultur des Friedens, eds. Nolz, Bernhard and Popp (Lit Verlag 2000) p. 110.

37 BGH, Urteil vom 19.06.1956 - 1 StR 50/56 (LG Augsburg). 
attempts to assassinate Adolf Hitler. According to documents found by the Gestapo, Canaris and his associates had been engaged in several plots to murder Adolf Hitler.

The Supreme Court dealt with the case three times. In the final round, it acquitted the two for their participation in the trials against Canaris and his associates. The Supreme Court had as its starting point that every state has a right to defend itself, and that the right to enact strong measures against attacks on the state, had to be extended to the Nazi state. The Supreme Court regarded the trials as ordinary trials, even though they had taken place as summary proceedings in the concentration camps where the accused were held, and based its ruling on the avowal of the defendants that they had perceived themselves free to perform their functions as judge and prosecutor according to the merits of the cases at hand. The trials were severely deficient from a procedural point of view, but the deficiencies of the trials were regarded as mostly 'formal'. In light of the burden of proof that must be met in a criminal case, the court held that it could not be established that the trials were not real trials, and that it could not in any case be established that the defendants did not perceive them as real trials. On these grounds, they were both acquitted, although Huppenkothen was punished for participating in the execution of the sentences without receiving the necessary confirmation from the higher authorities. The same standard was applied by Norwegian courts after the war in trials against German SS judges and members of German Standgerichte. ${ }^{38}$

In the Rehse case, the German Supreme Court stated that a judge could only be punished for voting for a death sentence if he so voted for nefarious reasons. ${ }^{39}$ Hans-Joachim Rehse had been a member of the Volksgerichtshof, in the words of US prosecutor Telford Taylor 'the most notorious Nazi judicial innovation'. ${ }^{40}$ In addition, Rehse had been co-assessor with the infamous Roland Freisler in many of his capital cases. The Supreme Court stated that the judges of the People's Court were independent, equal and only bound by the law. Their sole duty was to follow their own legal conviction. ${ }^{41}$ The judges serving here could only be held responsible for sentences they pronounced out of malicious reasons outside the scope of their legal beliefs.

We see that the case law against the Nazi judges based itself on the standard currently expressed by the Council of Europe. The rules that emerge from this case law are: Only judges acting maliciously can be held to account. A judge who keeps to his role as a judge, acting independently, cannot be met with criminal sanctions however unjust or oppressive the law is and however summarily the proceedings are, as long as there is some resemblance of a trail. The end result of the cases after the Nazi regime was that virtually

38 See Graver 2015 pp. 182-184 and The Latza case, reported in Law Reports of Trials of War Criminals vol. XIV, United Nations War Crimes Commission, London 1949.

39 BGH, Urteil vom 30. 4. 1968 - 5 StR 670/67.

$40 \quad$ The Justice Case p. 38.

41 BGH, Urteil vom 30. 4. 1968 - 5 StR 670/67. 
no judges were punished. In effect, the international tribunals and national courts alike allowed for a set of excuses and exonerating circumstances, thereby establishing a special judicial immunity.

Due to the burden of proof in criminal cases, a judge who denies that he has been acting under instruction or motivated by extraneous motives will hardly be convicted if his judgment was legally possible given the facts that were presented to him and the law at the time, provided only that the basics of a judicial procedure is followed.

\subsection{The Cases against Judges of the GDR}

German courts were called upon again to rule upon the responsibility of judges after the reunification of Germany in 1990. After Germany's unification, the German judiciary carried out a large-scale investigation and adjudication of the crimes of the GDR regime. The trials that were held can be seen as one of the steps taken to end the situation established by the courts after the breakdown of the Nazi regime - where crimes committed by the state apparatus in oppressive regimes went unpunished. ${ }^{42}$ Similar to the Nazi period, the judicial system of the GDR was also a system employed by the regime as an apparatus in the pursuit of political aims and as an instrument of political persecution and oppression. There were, however, also important differences. Compared to the Nazis, the GDR regime used law only in a marginal way to legitimise itself. ${ }^{43}$ On the other hand, the communist party conducted trials as mere show trials in a pseudo-judicial propaganda-play. In important cases, the punishment of the defendant was decided by the Central Committee of the party, before the indictment, and before any judicial proceedings had been held. ${ }^{44}$

The cases against prosecutors and judges of the GDR were the largest group of the cases initiated against representatives of the GDR regime for crimes against its population. ${ }^{45}$ Together 374 such cases against 618 accused were opened, $36.6 \%$ of the total number of the cases brought against former leaders and functionaries of the GDR state. Less than 5\% of the prosecutors and judges of the GDR were charged. The charges resulted in 181 convictions for 'bending the law', bringing the conviction rate to $24 \%$ of the accusations. In

42 See Marxen und Werle (Hrsg.), Strafjustiz und DDR-Unrecht Dokumentation, Band 5/1 Teilband Rechtsbeugung (De Gruyter 2007) p. XIX.

43 See Rottleuthner, Steuerung der Justiz in der DDR, 75 Kritische Vierteljahrersschrift für Gesetzgebung und Rechtswissenschaft (1992) pp. 237-264 at p. 119.

$44 \quad$ Werkentin 1994 p. 119

$45 \quad$ Marxen and Werle 2007 p. XXIX. 
addition, in a lot more cases the courts concluded that the judicial decisions had violated basic principles of the rule of law. ${ }^{46}$

Initially, the legal doctrine was sceptical to applying criminal sanctions against judges of the GDR regime. According to the opinions of many scholars, sanctions were ruled out because of the statute of limitation. In addition, many contested the rights of the Federal Republic as a successor to enforce infringements against the law in the GDR. ${ }^{47}$

The first case at the German Supreme Court was a case from 1993 against members of a labour court accused of upholding an unjust dismissal. ${ }^{48}$ Here, the Supreme Court stated that German courts could hold judges of the former GDR accountable, but that apart from cases of clear departures of the law of the GDR at the time, liability would have to be restricted to instances where the rights of individuals were substantially infringed in an obvious way to the point of being arbitrary. This restrictive approach followed from the prohibition against applying present law retroactively to the detriment of the GDR judges.

In determining what was to be considered as substantial and obvious infringements of individual rights, the Court referred to the International Covenant on Civil and Political Rights, which the GDR had ratified in 1976. Since this only formed part of the argument, one can say that the Supreme Court based its reasoning partly on positive law, in the form of ratified international conventions, and partly on the natural law argument of Radbruch. ${ }^{49}$ In the opinion of the Court, the judges of the GDR had had the possibility within the prevailing legal method to interpret and apply the law of the GDR in such a way as not to commit substantial and obvious infringements of individual rights understood in this way. For this reason, their judgments were also illegal at the time when they manifestly departed from the basic core of justice.

The objective conditions for applying criminal sanctions were elaborated in later cases. In the case of 16 November 1995 against a member of the Supreme Court of the GDR, the German Supreme Court recapitulated the following requirements: substantial and manifest human rights violations, intolerable disproportionate punishments and substantial violations of the right to a fair trial. ${ }^{50}$

The Supreme Court in this way made a clear break with its case law from the post-Nazi trials in their cases against the GDR judiciary. The Court explicitly accorded with the criticism which had been voiced against its jurisprudence of the 1950s and 60s. The Court

\footnotetext{
46 Marxen and Werle 2007 p. XXXVII.

47 See Schröder, Zehn Jahre strafrechtliche Aufarbeitung des DDR-Unrechts, NJW (2000) pp. 3017-3022, at 3019 .

48 BGH, Urteil vom 13.12.1993 5 StR 76/93.

49 See Marxen and Werle 2007 p. XLIII.

50 BGH, Urteil vom 16.11.1995, 5 StR 747/74.
} 
recognised that the standard they now applied would have led to the trial and conviction of numerous judges from the Nazi period - had it been applied by the courts in the aftermath after the Nazi regime. The Court stated that it was a 'momentous failure' of justice of the Federal Republic that this had not been done. ${ }^{51}$

\section{Making the Case for Criminal Liability of Judges}

\subsection{Judges Acting Illegally}

Based on the recommendations from international standard-setting bodies and examples of national law and cases where judicial liability has been the issue, we are ready to address the issue of criminal liability in more general terms. The question is not if, but when judges should be held accountable for oppressive rulings, and what the conditions of criminal accountability should be. We will look at this from different angels. Before we address the more difficult question of sanctioning judges for their acts within the law, we will make some observations on the situation when the judge is acting in a clearly illegal manner.

In many cases, authoritarian regimes restrict themselves to enacting oppressive laws, and leaves it to the courts to enforce these independently. Other authoritarian regimes are not as constrained in dealing with the judiciary. The Soviet authorities were notorious for their show trials and 'telephone justice' where judges were told directly by party official or the procurator how to decide certain cases. ${ }^{52}$ In its vicious form, this reduced the judges to 'mouthpieces' of the tyrants. ${ }^{53}$

Where the judge is under instruction, the resulting acts fulfil the condition of illegality. This is because the ruling is motivated by factors incongruous to the law, irrespective of whether the formal ruling is correct, judged by the facts or the law. In many of the show trials of the 1930ies and the 1950ies, the charges were of crimes that were invented for the purpose of the trial and based on facts that were fabricated by the security police. But the tragic fact is that in many cases defendants were guilty of breach of authoritarian and sometimes draconian laws, when they were charged with opposition to the regime

${ }^{51}$ 'Darin, daß dies nicht geschehen ist, liegt ein folgenschweres Versagen bundesdeutscher Strafjustiz' NJW 1996, 857, p. 864.

52 In the show trials, the decisions on whom to indict and what punishment to give them was made by the party in advance, and the prosecutor, judge and public defender were instructed in their roles and told in detail what to say during the trial. Even the defendant was given a script and instructed, see Pelikán (ed.) The Czechoslovak Political Trials, 1950-1954 (Stanford University Press 1971) pp. 110-114.

53 Parau, The Drive for Judicial Supremacy in Judicial Independence in Transition, ed. Sibert-Fohr (Springer 2012)p. 626. 
for example in the form of sedition or illegal political activity. This did not make their conviction legal. The point is that their conviction was not made according to a legal proceeding. For example, judges in special courts of Norway during the German occupation who passed death sentences under conditions where they were told that if they refused, many more than the defendants would be executed by the Germans, where convicted of murder after the war. ${ }^{54}$ Proceedings where the outcome was determined by the executive in advance, and where judges were used as a mere staffage to give the executions an appearance of legality, were not recognised as judicial acts by the Norwegian courts after the occupation.

The practice of 'telephone justice' prevails in many post-authoritarian states today. In a global review, Transparency International has found that despite several decades of reform efforts and international instruments protecting judicial independence, judges and court personnel around the world continue to face pressure to rule in favour of powerful political or economic entities, rather than according to the law. ${ }^{55}$ In many cases judges depend on being obedient to the presidential office or the hierarchical structure within the judiciary. It has been observed that in such cases, 'the caller may change, but the telephone calls continue.56

When interference into the judiciary is the norm, we encounter another problem with holding the judges individually accountable. In these cases, the individual culpability comes into question. ${ }^{57}$ The situation of judges under such conditions seems comparable to that of public servants of the regime in general. By succumbing to orders of the executive they become just that; servants of the regime or of the ruling party. From the point of view of criminal law one could argue that they should be treated as such; no immunity, but also no greater responsibility stemming from the fact that they are formally labelled as judges by the regime. Whereas one can argue that the public trust requires that criminal judges be brought to account, the situation is much more complex when it comes to public servants, since there is a different expectance of obedience and loyalty when it comes to public functionaries. Following a superior order to bend the law is not such an obvious crime for a bureaucrat as it is for a judge.

There is, however, an important difference between judges and other civil servants in the fact that the judges are the ones entrusted with the task of fulfilling the rights of the citizens to a fair trial. If a person charged with an offence is brought to trial and the judge decides the case based on an instruction received from someone else, he is depriving the

$54 \quad$ See Graver 2015 pp. 179-184.

55 Transparency International, Global Corruption Report 2007 Corruption in Judicial Systems (Cambridge University Press 2007) p. xxii-xxiii

56 Nußberger, Judicial Reforms in Post-Soviet Countries - Good Intentions with Flawed results? in Judicial Independence in Transition, ed. Siebert-Fohr (Springer 2012)p. 892.

$57 \quad$ See Murphy 2015 p. 67. 
accused of the right to a fair trial. The judge is therefore directly and personally responsible for infringing a human right of the accused. If the judge is acting under duress or threats, this could be an explanation, and possibly an excuse, but may never be a justification of the act.

\subsection{The Argument for Criminal Liability for Oppressive Judges}

The question is more complicated when it comes to judges who exercise an individual discretion within the law, as it is perceived at the time. The main problem of holding the Nazi judges accountable was that they were as a whole acting in accordance with the law as defined by their time. The independence of the judiciary was mostly upheld and respected by the Nazi authorities. Trials were held that respected at least the rudiments of a fair trial, and the judges were not given instructions on how to decide individual cases. ${ }^{58}$ There were exceptions from this picture, but the cases after the fall of the regime against judges were cases where the judge had come to his ruling independently, based on the facts and the law. The judges oppressed opposition to the regime, but this was a consequence of the fact that the law oppressed enemies of the people and the 'German blood'.

As we saw above, the Nazi judges went scot-free. This was not the case with the GDR judges who were convicted for bending the law, even where there was no evidence to support the fact that they had acted under instruction. It can be argued that the German courts after the reunification of Germany went too far in their endeavour to rectify the sins of omission of their predecessors after the war. The standard of proportionality is open to judgement, and so is the condition of substantive violations. This must be seen in relation to the fact that the standards are applied to conditions where the judgments are made in accordance with the established practice and dominant opinion on what the law is at the time of its application. A judge can therefore according to this standard be held accountable for loyal application of positive law, if the legal practice itself amounts to substantial violations of human rights or applies punishments that are intolerable disproportionate. According to this standard, US judges applying sentencing rules in circumstances where minor offences lead to life-time imprisonment without possibility of parole, could be committing a criminal offense, at least if judged by European standards under Article 5 ECHR.

Discretionary standards of liability are of particular danger in societies where the rule of law is not well established as part of the political and legal tradition. Pressure on judges is applied in many ways, and one such way is to instigate bogus criminal proceedings against judges who refuse to bend to the demands of outside forces. If the judiciary in general is weak, this increases the risk of miscarriage of justice in such cases, so that 
honest judges may be wrongly convicted on false charges of corruption or other forms of misuse of office. ${ }^{59}$ In such situations, there is a trade-off between protecting the honest judges from false allegations, and letting the judges who are actually guilty of various forms of misuse enjoy immunity. Seen in a dynamic perspective, the rule of law may be better served by insisting on judicial immunity when the judiciary as such lacks independence from the state. There is a trade-off for holding judges accountable for past sins, particularly in a society struggling to build an institution of independent judges with integrity to follow the rule of law.

In the Russian Federation, judicial immunity was restricted by a reform package of 2001. According to the new regulations, judges could face criminal charges for 'both official and non-official actions demonstrating constituent elements of a relevant offence. ${ }^{60}$ The Polish Constitutional Court is also aware of this danger when it states:

The significance of judicial immunity is particularly profound in countries where democracy and mechanisms for the separation of powers have not yet been consolidated. Independence of judges and courts may exist without the need for the institution of immunity in countries of mature democracy, already-fixed understanding of the separation of powers and high legal and political culture, as these factors minimise the political risk of abusing the possibility of a judge's removal from office owing to the content of judgements delivered by them. ${ }^{61}$

This argument states a need of different standards of immunity in the established rule of law states and the states where the institutions of the rule of law are more exposed to erosion. However, this coin has two sides. On the one hand there is a need to protect the judges who try to uphold the rule of law under such circumstances against adverse measures from the executive and collaborating judges. On the other hand, it is necessary to be able to hold judges who collaborate with the regime in the breakdown of the rule of law when the rule of law is (re)established, accountable. How can one achieve this without undermining the position of courageous judges in opposition to oppressive regimes, by legitimizing the use of sanctions against them?

This dilemma calls for a cautious approach to the criminalisation of judges, particularly in times of transition and political instability. In political settings where a tradition with respect for the judicial independence is lacking, pressure may be applied on judges to decide cases in specific ways by many means. Criminal proceedings against a judge could

59 Dal Bó, Dal Bó and Di Tella, Bribes, punishment and judicial immunity, Transparency International, Global Corruption Report 2007 Corruption in Judicial Systems (Cambridge University Press 2007) p. 305.

60 Schwartz and Sykainen, Judicial Independence in the Russian Federation in Judicial Independence in Transition, ed. Siebert-Fohr (Springer 2012) p. 1035.

61 Judgement of 28th November 2007, K 39/07 PROCEDURE FOR DEROGATION OF JUDICIAL IMMUNITY (OTK ZU 2007, No. 10A, item 129 ) paragraph 15 (accessed 20.05.2016 at http:// trybunal.gov.pl/fileadmin/content/omowienia/K_39_07_GB.pdf) 
be one. Charges of corruption are often employed against oppositional judges. To avoid this, one could argue that judges should have full immunity against criminal charges, and not only a functional immunity. At the least, the decision to press charges against a judge, or to lift the immunity against charges, should not be in the hands of the executive, of the prosecuting authority or any other political body. In addition, a judge should have access to an independent and impartial review of an action brought against him or her.

Full immunity will, however, be to go too far, and can contribute to undermining the confidence of the public in the judicial system. There is a legitimate need to be able to remove and punish judges who commit obvious crimes outside the scope of their official functions. If judges are immune at the outset, there will therefore always be a need of mechanisms to lift this immunity in individual cases - and such mechanisms are prone to misuse. The recommendation of the Venice commission that immunity be reserved to a functional immunity therefore seems sound. At the same time, it is important that the separation of the judiciary from other state powers is ensured and that the legal order provides for appropriate guarantees, both in law and practise, against the misuse of criminal and disciplinary measures to the detriment of judicial independence. ${ }^{62}$ In countries with an established practise of interference into the work of the judiciary, the application of sanctions will always be ground for suspicion, since it is an effective way of disciplining judges who refuse to keep in line.

Judges should not have privileges that go beyond what is necessary for their function as protectors of the rule of law. This does not imply, however, that they should have full functional immunity against criminal prosecution. Taking the protection of the rule of law as a starting point, one could argue that their responsibility should stretch further than to cases of malice. As we see from the post-Nazi trials, a condition of malice will in practice lead to the fact that judges are not accountable for their participation in crimes committed by authoritarian regimes in legal forms, whereas policy-makers, administrators and members of other professions are held to account. Such a result is hard to accept, and speaks against the keeping of the independence of the judiciary. As stressed in international documents on judicial independence, the independence of judges is not a prerogative or privilege in their own interest, but in the interests of the rule of law and those seeking and expecting justice. ${ }^{63}$

When judges are engaged in a systematic undermining of the rule of law, the argument of judicial independence therefore should not protect them against responsibly. A judge thus engaged, can hardly plead ignorance of wrongdoing. In the case of the leaders 2013 paragraph 199.

63 Opinion no 1 of the Consultative Council of European Judges (CCJE) concerning the independence of the judiciary and the irremovability of judges paragraph 10 . 
of the GDR, who developed and enforced the scheme of killing those who tried to escape over the border to West-Germany, the European Court of Human Rights stated:

The State practice in issue was to a great extent the work of the applicants themselves, who, as political leaders, knew - or should have known - that it infringed both fundamental rights and human rights, since they could not have been ignorant of the legislation of their own country. ${ }^{64}$

In this case the right to life and the principle of proportionality when applying deadly force was well established in the law, but was disregarded in the orders and practice that was enforced in the control of the border. The same reasoning must be applied to a judge who systematically and obviously undermines basic and essential elements of the rule of law, such as the independence of the judiciary and fundamental human rights.

Then the issue is transferred from the question of the subjective intent of the judge, to the question of when a judge is engaged in a scheme of systematic undermining of the rule of law. Under certain circumstances, this is not only a breach of national law, but also an offence that is made criminal directly by international law, both as regards to the prohibited conduct and the individual criminal responsibility for it. This criminal responsibility follows from international customary law, particularly after the Nuremberg and Tokyo trials. It is now codified in the Rome Statute of the International Criminal Court. After the international adoption of the Rome Statute, judges can be guilty of genocide and crimes against humanity when applying and enforcing the domestic law. In the future, this should be the standard according to which judges should be brought to account.

Under international human rights law, states have an obligation to prosecute perpetrators of serious human rights violations. According to the jurisprudence of the European Court of Human Rights, member states must criminalise and punish violations of fundamental values and aspects of the human rights entailed in the European Convention. ${ }^{65}$ It has been shown for a long time that also judges can be responsible for atrocities under international law, committed as part of the application and enforcement of domestic law. This was first established by the US Military Tribunal against leaders of the Nazi legal system, and has since been confirmed by the European Court of Human Rights.

The Nuremberg trials showed that judges can be held responsible under international law, not only for war crimes, but also for administering the law against a country's own nationals. The Military Tribunal established that it was a crime for judges to administer laws that were part of the regime's discriminatory policy and extermination of Jews and

64 ECtHR case of Streletz, Kessler and Krenz v. Germany (Applications nos. 34044/96, 35532/97 and 44801/98) judgement 22 March 2001 paragraph 103.

65 In for instance ECtHR case of K.U. v Finland, application no 2872/02, Judgement of 2 December 2008. 
Poles, and to undertake an arbitrary and brutal enforcement of oppressive laws 'shocking to the conscience of mankind'.

Because of the findings of the Tribunal, judges may be held accountable under the Rome Statute of the International Criminal Court. Based on the statute, judges can be found guilty of genocide and crimes against humanity also when applying and enforcing municipal law. According to Article 7(2) a, an attack against any civilian population means a course of conduct 'pursuant to or in furtherance of a State or organizational policy to commit such attack. Enforcing the laws of the regime cannot be a defence. On the contrary, it serves as a factor substantiate that the condition of furtherance of a State policy is fulfilled. ${ }^{66}$

International law is, as we know, not directly applicable in domestic law in all jurisdictions, at least not as a sufficient legal basis for applying criminal sanctions or to supplant rules of domestic law. Whether judges can be held responsible by national courts must therefore be answered within each legal order according to its own legal principles and rules. But the German experiences, together with the fact that judges can be punished by international courts and tribunals, give valuable insights and arguments to be considered when addressing this question in a national legal contexts.

It seems at the outset quite reasonable to assume that there exists a core of justice, present in the minds of 'all civilized people', and that to this core belong substantial and manifest human rights violations, intolerable disproportionate punishments and substantial violations of the right to a fair trial. On the other hand, the words of the US Military Tribunal on the draconic punishments delivered by German courts during the war, with the minimum of procedural guarantees, are a note of caution to finding self-evident requirements of justice: 'Every nation recognizes the absolute necessity of more stringent enforcement of the criminal law in times of great emergency' and

in the face of a real and present danger, freedom of speech may be somewhat restricted even in America. Can we then say that in the throes of total war and in the presence of impending disaster those officials who enforced these savage laws in a last desperate effort to stave off defeat were guilty of crimes against humanity? ${ }^{27}$

What seems beyond question to many people today might not be so self-evident to people in a totally different setting tomorrow. At least, it was not so to the defenders of democracy and the rule of law in 1948. On the other hand, to become an international legal rule, a practice needs not be a universally recognised. It is sufficient that it is accepted by civilised nations in general. ${ }^{68}$

$66 \quad$ See The Justice Case p. 984.

67 The Justice Case p. 1026.

68 See Law Reports of Trials of War Criminals, vol. XV Digest of Laws and Cases, United Nations War Crimes Commission, London 1949 p. 10. 
It appears to be very difficult to find a fixed core of justice that can be seen as intuitively valid as law under all conditions and at all times. Regimes can decide to depart from international obligations in their own internal law, and judges be put under an obligation to enforce it. Morally, they can be under an obligation to refuse, resign or to find ways to bend the law, but to say they are guilty of crimes under their own law is a different question. At the same time, however, they might be committing criminal acts from the perspective of international law.

The standard 'substantial and obvious infringements of individual rights' might be considered by some as vague and of little guidance for determining the extent of the obligation of judges. As such, some might argue that it is in itself in contradiction to the rule of law. The way the standard has been applied gives little credence to this objection. It could, nevertheless, be useful, not least as guidance to judges who find themselves in a difficult situation, to give the standard a little more substance. A useful starting point can be found in the Rome Statute of the International Court of Criminal Justice. Articles 6-8 define the crimes of genocide, crimes against humanity and war crimes as they are under the jurisdiction of the ICCJ.$^{69}$ Prohibitions against slavery, genocide, racial discrimination and torture are among the norms frequently cited as jus cogens - that is basic norms of international law which are universally binding and cannot be contracted away.

Central to the definition of genocide is the intent to destroy, in whole or in part, a national, ethnical, racial or religious group. Central to the definitions of crimes against humanity and war crimes are that the acts represent a widespread or systematic attack or are part of a plan or policy or of a large-scale commission. Use of legislative means will often include intent, policy and actions on a widespread or systematic scale. When giving effect to such laws, judges will easily be in a situation where these conditions are fulfilled, as shown by the US Military Tribunal against the Nazi lawyers. In its introductory comments to the application of Control Council Law No, 10 as legal basis for punishment it stated:

As we construe it, that section provides for punishment of crimes committed against German nationals only where there is proof of conscious participation in systematic government organized or approved procedures amounting to atrocities and offenses of the kind specified in the act and committed against populations or amounting to persecutions on political, racial, or religious grounds. ${ }^{70}$

The inclusion of a condition of 'systematic government organized or approved procedures' by the Military Tribunal, of 'widespread or systematic attack or as part of a plan or policy or as part of a large-scale commission' by the Rome Statute, in addition to the condition of 'substantial and obvious infringements of individual rights' lends more substance to

69 See Jescheck 2004 on the relationship between the Nuremberg trials and the ICC statute.

70 The Justice Case p. 982. 
the norm as a basis for criminal sanctions. Based on historic experience, it seems unlikely that successor regimes will go much further than this in their dealings with offenders of predecessor oppressive regimes. To include a requirement of systematic attacks will therefore probably not reduce the efficiency of transitional justice in dealing with the aftermath of dictatorship. However, it will heighten the standard of the rule of law in such proceedings and check arguments based on assertions that 'substantial and obvious infringements of individual rights' is too vague a standard to apply in criminal proceedings against a judge who had been applying the law of the time.

Judges who are called upon to enforce authoritarian or oppressive measures should take note of the prohibitions against 'imprisonment or other severe deprivation of physical liberty in violation of fundamental rules of international law and persecution against any identifiable group or collection on political, racial and other grounds'. These prohibitions will easily be violated when enforcing measures of interning people in opposition and criticism of the regime in power. When such measures are enacted in, for example, emergency legislation, they must readily be regarded as systematic and as part of a plan or policy. The same is the case if justice is systematically denied members of a political or ethnic group.

For deprival of the basic minimum of a fair trial or for grossly unjust punishments, it is not obvious that there needs to be an element of discrimination included. The ECtHR has recently stated that fundamental principles of justice can limit the punishments that legally can be inflicted by a state upon defendants in criminal cases. In its judgment in the case of Vinter and other v. the UK, the Grand Chamber of the ECtHR accepted that a grossly disproportionate sentence could amount to ill-treatment contrary to Article 3, even if matters of appropriate sentencing largely fell outside the scope of the European Convention. ${ }^{71}$

However, the Court also considered that 'gross disproportionality' is a strict test, and that it would only be on 'rare and unique occasions' that the test would be met. Having violations of fundamental rights in a systematic manner as the condition for judicial responsibility, removes the cause for arguments that judicial responsibility threatens the independence of the judiciary. Such systematic violations can never be justified by an appeal to the rule of law. At the same time there is no need to prove malicious intent to punish an individual judge. Criminal guilt can be established by the objective facts, together with the fact that no judge can claim with credibility that he was unaware of doing something wrong. This means that it is actually possible to find a judge guilty under the presence of the presumption of innocence and the burden of proof of the prosecution. Defining the criminal responsibility in this way is also less prone to misuse by authoritarian rulers as an instrument to discipline disloyal judges. The conditions will simply

ECtHR case of Vinter and others v. the United Kingdom Applications nos. 66069/09 and 130/10 and 3896/10, Judgement of the Grand Chamber of 9 July 2013 paragraph 102. 
not be fulfilled unless the judge is acting in accordance with a more general policy of the authorities in power. The conditions are also much harder to misconstrue than a requirement of 'departure from the law' or 'malicious intent' that are the terms often used to define judicial responsibility. 